\title{
The Attitudes of Islamic Education Teachers Towards the Use of Social Media in Teaching and Learning
}

\author{
Badr Abdullah Al-Harbi ${ }^{1}$ \\ ${ }^{1}$ Faculty of Education, Hail University, Hail, Saudi Arabia \\ Correspondence: Badr Abdullah Al-Harbi, Faculty of Education, Hail University, Hail 2440, Saudi Arabia.
}

Received: May 14, 2019

Accepted: July 26, 2019

Online Published: October 28, 2019

doi:10.5539/ies.v12n11p154

URL: https://doi.org/10.5539/ies.v12n11p154

\begin{abstract}
The aim of this study was to identify and analyse the Islamic Education teachers' attitudes, difficulties and purposes while using social media in the educational processes in the Saudi context. In doing so, this study adopted a quantitative, descriptive approach based on empirical data collected by means of a questionnaire. The study sample consisted of 124 teachers of Islamic Education in Hail, Kingdom of Saudi Arabia (KSA). While the participants reported positive attitudes towards the use of social media in the educational processes, the results showed their low use of social media which was limited mainly to personal purposes rather than using them for teaching learning activities. Based on the results, the study recommends developing teachers' knowledge and skills to make them aware of the use of social media in education and encourage them to utilize them for teaching and learning activities. Since social media are ubiquitous and being widely used for personal reasons, their integration into the curricula and syllabi may further increase the teaching and learning of Islamic Education in Saudi Arabia.
\end{abstract}

Keywords: social media, educational process, attitudes, Islamic education

\section{Introduction}

There have been recent successive developments in various fields, especially in the field of information and communication technology (ICT). The emergence of the internet is one of the reasons for this tremendous development which has resulted in the easy access and exchange of information. The advent of the internet and its widespread use is one of the most important reasons that led to a rapid and massive development in science and to the interconnection of the world. This has also facilitated the rapid transmission of information anywhere in the world and the World Wide Web has now entered various areas of life thereby reducing time and effort (Al-Sadhan, 2015).

Since 2003, as mentioned Redecker, Ala-mutka, and Punie (2010), the internet has seen a stunning growth in applications controlled by the end user such as blogs, podcasts, wikis, social media, navigators, auction websites, games and Voice over Internet Protocol services, in addition to the emergence of web 2.0 technologies. The term Web 2.0 or social computing refers to a range of digital applications that enable the user interaction and collaboration and the sharing of data between users, in addition to the applications of digital blogging, podcasts and collaborative content such as wikis. Social media (e.g. My Space, Facebook) and the sharing of multimedia can be considered as part of the Web 2.0 applications and are part of the internet programs that help learners learn, share information and collaborate with others through digital communications (Redecker et al., 2010).

The term social media refers to modern terminologies relating to a variety of tools or networking technologies that focus on the social aspects of the internet as a channel of communication, cooperation, creative and social expression (Dabbagh \& Reo, 2011). According to Hurn (2012), social media are software applications that support the interaction between members of a group and enable the social communication and interaction of groups through Web cooperation and the exchange of information in environments based on the Web.

Recent statistics indicate an increasing number of users of social media in the world and particularly in Arab countries. The Arab Social Media Report issued by the Mohammed Bin Rashid College revealed a significant increase in the number of social media users in the Arab countries (Salem, 2017). Facebook is one of the most popular social media platforms in the Arab world, with about 156 million users in 2017 compared to 115 Million users in 2016. The total number of active Twitter users per month in the Arab world is estimated at 11.1 million in March 2017 compared with 5.8 million in 2014. Saudi Arabia, for instance, has the highest number of active 
Twitter users in the region, with more than 2.6 million active users, representing $29 \%$ of all active users in the Arab world (Salem, 2017).

The influence of social media has continued to grow globally over the past decade. During this period, the scope and the scale of use has changed significantly from the early days, when social media primarily achieved social needs of communication such as socialisation and entertainment, to the present era where social media applications are seen as important tools for development, diplomacy, business and education (Salem, 2017).

In terms of education, information technology has gradually been integrated into the learning processes as emerging technologies, such as social media, have helped teachers and learners develop their skills and enhance their autonomy in learning. This is because social media have eliminated spatial and temporal constraints that made communication and access to knowledge difficult and limited in scope (Aifan, 2010). The spread of social media has facilitated access to information for teachers and learners alike giving them more flexibility in teaching and learning, including communication with specialists in the same field. Social media have also helped to bridge the gap among young people by allowing teachers to diversify their use in the field of education. In this regard, Soomro, Kale, and Zai (2014) found that certain teachers use social media to attract students or help students in the process of teaching and learning while others use social media to build professional networks between teachers themselves and between teachers and students.

Moreover, Abdulhafez (2012) points out that social media play a major role in the teaching and learning process as these tools can help the teacher to learn about the latest developments in his or her field of teaching and encourage students to conduct research about various subjects of their courses. Social media also contribute to the active participation of learners by inviting them to add topics for dialogue and share with their colleagues' information, pictures or videos on the subject.

This change and diversity in the process of teaching and learning and the entry of social media in the field of education have imposed on the teacher a new reality where the sources of knowledge are now numerous for the learner who has more opportunities to acquire knowledge and skills than the past. Hence, this makes it imperative for teachers to address this change so that they are able to benefit from social media in the educational process and the provision of appropriate expertise (Al-Ghamlas \& Al-Qumizi, 2016).

As a result, the rapid growth in the use of these networks by students and their use as educational platforms by the teachers interested in this field may contribute to the development of the educational process by re-shaping the relationship between the teacher and the student and therefore enhancing the effectiveness of learning. Hence, this study sought to identify the attitudes of teachers of Islamic Education in the city of Hail towards the use of social media in the educational process.

\subsection{Research Problem}

Based on the widespread use of social media and the students' need for new learning environments that help them enhance their learning, maintain its impact, acquire the necessary skills and knowledge, and transform the role of the student from a recipient of information to a researcher. As a Saudi educator, the researcher noticed during his work as supervisor in public school that teachers held different views regarding the use of social media in education as well as their attitudes towards them. In addition, several studies have revealed the effectiveness of social media in terms of enhancing the achievements of students and facilitating the dissemination of knowledge in society. For example, the studies of Al-Anzi (2013) and Hassanein (2013) have recommended the use of social media in the field of education. Based on the studies above, this study sought to reveal the attitudes of teachers of Islamic Education in the city of Hail towards the use of social media in the educational process and the difficulties faced by teachers of Islamic Education in Hail when using social media in education.

\subsection{Research Questions}

The study seeks to answer the following questions:

1) What are the attitudes of teachers of Islamic Education in Hail towards the use of social media in the educational process?

2) What are the perspectives of teachers of Islamic Education in Hail about the purposes of the use of social media in the educational process?

3) What are the difficulties facing Islamic Education teachers in Hail when using social media in the educational process?

\subsection{Significance and Contribution of the Study}

This study has the potential to make a significant contribution in the following areas. First, in response to the 
technical development and the trend to integrate it in the process of teaching and learning in order to improve the educational system and involve the teacher in the educational process.

- The results of the study will contribute to providing officials in the Ministry of Education and decision makers with the attitudes of teachers of Islamic Education towards the use of social networks in the educational process.

- The results of this study will contribute to highlight the most important difficulties faced by teachers when using social media in education.

- $\quad$ The results of the study and its recommendations may contribute to open the way for researchers to address the issue of activating social media in the educational process from other aspects.

\section{Literature Review}

In the following sections, the paper reviews some of the most relevant literature pertaining to the use of social media in teaching and learning focusing on previous studies investigating the three key areas of interest for this study: (1) the attitudes towards the use of social media in education, (2) the purposes of using social media in teaching and learning and (3) the challenges faced by teachers when introducing social media in the educational process.

\subsection{Attitude towards the Use of Social Media Teaching and Learning}

Several research studies have been conducted to explore teachers' attitudes towards the use of social media in education in general and in teaching and learning in particular. For instance, S. Yuen, Yaoyuneyong, and P. Yuen (2011) surveyed 1200 teachers at all levels (secondary, elementary and, college/university) in the State of Mississippi in order to determine their perceptions and willingness to learn about, adopt, and integrate Web 2.0 technologies into their classrooms. The study found that teachers reported positive attitudes regarding the use of social media in teaching and learning. Likewise, Ibrahim's (2014) study aimed to identify the extent to which faculty members and students in the universities of Upper Egypt used social media in the educational process at university. The researcher administered a questionnaire among a sample of faculty members from Sohag University, Assiut University, and South Valley University. The study was conducted among 600 participants and concluded that both students and faculty members had positive attitudes towards using social media in teaching and learning. Moreover, Al-Otaibi (2018) conducted a study to identify the attitudes of teachers towards the use of social media and their importance in education and the obstacles to their use from their point of view. In order to achieve these objectives, a descriptive method was employed and a questionnaire was designed and administered to a sample of 140 female teachers. The results showed that the participants had positive attitudes towards social media.

Moreover, a study by Roebuck and Bell (2013) investigated the use of mobile devices and social media tools by faculty members of various disciplines in teaching and learning. The study sample comprised 201 participants working at Kenesaw University in the US. The results indicated that faculty members, whether male or female, with different degrees tend to use social media in their teaching and have positive attitudes towards them. Furthermore, in the context of Turkey, Acarli and Sağlam (2015) conducted a study to investigate pre-service teachers' intentions who were studying at Ankara University making use of social media in teaching activities. The survey was implemented to 322 pre-service teachers who were students in different teaching programs. The study employed a questionnaire as the main tool of data collection. The results of the study showed that participants had positive attitudes towards the use of social media in professional lives.

\subsection{Purpose of Social Media Use}

Several studies have focused on the purposes of social media use in education settings. Al-Yahya (2014), for instance, analysed the level of social media use in the educational process in order to determine the difficulties of social media use by teachers and students in the educational processes at Princess Noura bint Abdul Rahman University. The study found that most participants used social media for about one to two hours a day and consulted social media websites at an average of three times or more per day. Moreover, the study also revealed that the main motivations for using social media in the educational process were the convenience of exchanging ideas and opinions, which might lead to student learning to use educational techniques.

In another study, Ibrahim (2014) found that faculty members in Egyptian universities often used social media, particularly Facebook while the students used them in the educational process to a great extent in cooperation with their peers. However, the study noted that the use of social media for collaboration with faculty members was low. Likewise, Taha (2016) conducted a study to examine the use of social media by student teachers and its role in supporting educational process at Taif University in Saudi Arabia. The researcher used an analytical descriptive 
research method, and an experimental design to study a sample of 150 female students specialised in educational technology during the first semester of the academic year 2015/2016. The study revealed that that $89.7 \%$ of the student teachers participating in the study used social media in the educational process.

Furthermore, Al-Maliki and Al-Mas'ad (2017) investigated the role of social media in developing the teaching practices of middle and secondary school mathematics teachers from their point of view. The researchers used a descriptive approach employing a survey focusing on four main issues: lesson planning, lesson implementation, assessment, exchange of experiences. Data collected from 115 teachers suggested that the overall results of the questionnaires were high, indicating that social media played an active role in education process. The responses of male and female teachers in the areas of lesson planning and exchange of experiences were higher than the other two components. The Whatsapp platform reached the highest percentage in terms of use and effectiveness (66\%) from mathematics teachers' point view. Finally, the study recommended using social media for the purpose of communication between students and teachers and suggested providing teacher training to maximize the benefits of social media by developing their skills.

Still in the Saudi context, Al-Sadhan (2015) explored the use of social media (Twitter and Facebook) in teaching by faculty members at King Saud University. To achieve these goals a sample of 549 members was chosen. The results of the study showed that the use of social media in university teaching was not achieved its potential. Similarly, Soomro, Kale, and Zai (2014) conducted a study to examine Pakistani pre-service teachers' and teacher educators' current use of Facebook and their attitudes towards this tool for collaborative learning. The study, conducted at a public sector university in Pakistan, showed that the main use Facebook for the majority of pre-service teachers and teacher educators were mainly for social purposes. For example, they used it to keep in touch with family and existing friends or to make new ones.

In another study, Al-Ghamlas and Al-Qumaizi (2016) sought to measure the extent to which faculty members of Saudi universities employed social media in planning, implementation and evaluation of the teaching and learning processes. The study sample comprised 266 male and female faculty members from Prince Sattam bin Abdul Aziz University and Al-Majmaa University. The findings showed that, based on the participants' responses, the level of social media utilisation was medium in planning the teaching and learning processes, as well as in the implementation of the teaching and learning processes. The study revealed that the faculty members didn't seem to be enthusiastic about use of social media in the evaluation of teaching and learning. The researchers recommended establishing a modern electronic system in Saudi universities, to help faculty members use social media in education settings. The researchers also emphasised the need to develop social media users' skills for teaching and learning and recruit staff at Saudi universities to provide technical support to their faculty members.

\subsection{Challenges Facing the Use of Social Media in Education}

Several studies show that teachers have encountered problems to use social media for educational purposes. For example, Ibrahim (2014) claimed that despite teachers' strong desire to integrate and use social media in the educational process, their lack of knowledge and skills often stifled the use of social media for educational activities. Al-Sadhan (2015) also investigated the use of social media (Twitter and Facebook) in teaching by faculty members at King Saud University and the difficulties they encountered while using them. The faculty members reported that they required training to enhance their skills and knowledge to use social media in their teaching. In this regard, Kale and Goh (2012) believed that the success of implementing social media for teaching learning hinges largely on the training providing skills to navigate in the program, manage resources, and communicate with other participants.

In addition, the administrative obstacles that hinder the use of these media by teachers were raised by several researchers. For example, teachers complained about the absence of regulations supporting the use of social media in the educational process (Ibrahim, 2014). Therefore, Roebuck and Bell (2013) argue that there is a need to have an institutional approach to explain why social media can be useful and how it can be used in teaching and learning.

The lack of time to use social media has also been identified as a difficulty. For example, Al-Otaibi (2018) mentioned that the lack of time to use social media in education against many tasks that teachers must do was seen as the most significant difficulty facing teachers in using social media in teaching. She pointed out that teachers felt that they had not enough time to use social media because of their heavy teaching load which put more pressure on them.

\section{Methodology}

Considering the nature and objectives of the study, the researcher employed a quantitative approach, which aims at 
describing a phenomenon, determining its contributing causes and effect. Data were collected using a questionnaire comprised three main sections and a total of 345 items.

\subsection{Sample and Population}

The current study target population consists of all teachers of Islamic Education within the schools under the supervision of the Department of Education in Hail city for the second semester of the year 2017/2018. At the time of conducting this study, the total number of teachers was 360 (Population), where they all were chosen as the sample of this study using the non-probability sampling strategy. Cohen et al. mentioned that "this is frequently the case in small scale research, for example, as with one or two schools, two or three groups of students, or particular group of teachers, where no attempt to generalize is desired" (p.102). The response rate was 124 out of 360 (34\% of whole population) which can be considered a representative sample.

\subsection{Instrument of Data Collection}

The current study used a questionnaire as a tool for collecting data from the study sample. The questionnaire was designed based on previous studies and the literature related to using social media in education. The questionnaire consists of three sections: the first section includes 20 items about the attitudes of teachers towards the use of social media in the educational process. The second section consists of 3 items, which probes into the purposes for which social media are used by teachers in the educational process. The third section consists of 12 items about difficulties facing the teachers when using social media in the educational process. Participating teachers of Islamic education in Hail were randomly selected and the sample consisted of 124 teachers representing $34 \%$ of the target population.

\subsection{Validity}

Before it was administered for the main study, the questionnaire was presented to a group of experts (10) among the faculty members of the University of Ha'il and in light of their comments, adjustments were made by the researcher and the questionnaire was finalised.

\subsection{Reliability}

The consistency test of the questionnaire was conducted on a sample of fifty teachers by calculating the coefficients of Alpha Cronbach for all the items of the questionnaire, and the expressions of each axis separately.

Table 1. Reliability analysis

\begin{tabular}{clcc}
\hline No. & Scale & No. of Items & Cronbach's Alpha \\
\hline 1 & Utilisation of social media in teaching & 20 & 0.947 \\
2 & Difficulties in using social media in teaching & 12 & 0.828 \\
Total & & 32 & 0.886 \\
\hline
\end{tabular}

Table 1 above shows that the Cronbach's alpha was $0.947,0.828$ and 0.886 for the first scale (utilisation of social media in teaching), the second scale (difficulties in using social media in teaching). This indicates that the questionnaire was reliable.

\section{Results and Discussion}

The results of the study derived from the participants' responses are presented and discussed below based on each research question.

\subsection{Question One: What Are the Attitudes of the Teachers of Islamic Education in Hail Towards the Use of Social} Media in the Educational Process

To answer this question, the researcher calculated the frequencies, percentages, arithmetical averages, and standard deviation of teachers' responses to items related to their attitudes towards the use of social media in teaching and learning as showed in Table 2. 
Table 2. Teachers' attitudes towards the use of social media in teaching

\begin{tabular}{|c|c|c|c|c|c|c|c|c|c|c|}
\hline No. & Statement & & $\begin{array}{l}\text { Strongly } \\
\text { Agree }\end{array}$ & Agree & Neutral & Disagree & $\begin{array}{l}\text { Strongly } \\
\text { Disagree }\end{array}$ & $\stackrel{\Xi}{\Xi}$ & $\frac{7}{\omega}$ & 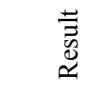 \\
\hline \multirow{2}{*}{1} & \multirow{2}{*}{$\begin{array}{l}\text { I believe that social media is } \\
\text { easy to use }\end{array}$} & Frequency & 69 & 49 & 5 & 1 & 0 & \multirow{2}{*}{4.5} & \multirow{2}{*}{0.618} & \multirow{2}{*}{$\begin{array}{l}\text { Strongly } \\
\text { Agree }\end{array}$} \\
\hline & & $\%$ & 55.6 & 39.5 & 4 & 0.8 & 0 & & & \\
\hline \multirow[b]{2}{*}{2} & \multirow{2}{*}{$\begin{array}{l}\text { I opt for using social media as it } \\
\text { is a valuable resource of } \\
\text { information for the course I } \\
\text { teach }\end{array}$} & Frequency & 32 & 55 & 22 & 10 & 5 & \multirow[b]{2}{*}{3.8} & \multirow[b]{2}{*}{1.044} & \multirow[b]{2}{*}{ Agree } \\
\hline & & $\%$ & 25.8 & 44.4 & 17.7 & 8.1 & 4 & & & \\
\hline \multirow[b]{2}{*}{3} & \multirow{2}{*}{$\begin{array}{l}\text { I believe that using social media } \\
\text { sites as an educational tool } \\
\text { could overcome the defects of } \\
\text { traditional education }\end{array}$} & Frequency & 40 & 43 & 30 & 7 & 4 & \multirow[b]{2}{*}{3.87} & \multirow[b]{2}{*}{1.036} & \multirow[b]{2}{*}{ Agree } \\
\hline & & $\%$ & 32.3 & 34.7 & 24.2 & 5.6 & 3.2 & & & \\
\hline \multirow[b]{2}{*}{4} & \multirow{2}{*}{$\begin{array}{l}\text { I think that social media is } \\
\text { crucial for the education } \\
\text { process }\end{array}$} & Frequency & 40 & 45 & 25 & 9 & 5 & \multirow[b]{2}{*}{3.85} & \multirow[b]{2}{*}{1.08} & \multirow[b]{2}{*}{ Agree } \\
\hline & & $\%$ & 32.3 & 36.3 & 20.2 & 7.3 & 4 & & & \\
\hline \multirow[b]{2}{*}{5} & \multirow{2}{*}{$\begin{array}{c}\text { I believe that using social media } \\
\text { is useful for enhancing } \\
\text { students' learning }\end{array}$} & Frequency & 42 & 45 & 22 & 13 & 2 & \multirow[b]{2}{*}{3.9} & \multirow[b]{2}{*}{1.039} & \multirow[b]{2}{*}{ Agree } \\
\hline & & $\%$ & 33.9 & 36.3 & 17.7 & 10.5 & 1.6 & & & \\
\hline \multirow{2}{*}{6} & \multirow{2}{*}{$\begin{array}{l}\text { Communication through social } \\
\text { media is inexpensive }\end{array}$} & Frequency & 52 & 44 & 17 & 9 & 2 & 400 & 0006 & A rreo \\
\hline & & $\%$ & 41.9 & 35.5 & 13.7 & 7.3 & 1.6 & 4.09 & 0.996 & Agree \\
\hline & I believe that using social media & Frequency & 42 & 44 & 20 & 14 & 4 & & & \\
\hline 7 & $\begin{array}{l}\text { is useful for creating an } \\
\text { atmosphere for discussions and } \\
\text { debates among students }\end{array}$ & $\%$ & 33.9 & 35.5 & 16.1 & 11.3 & 3.2 & 3.85 & 1.109 & Agree \\
\hline 8 & I would rather use social media & Frequency & 28 & 32 & 27 & 23 & 14 & 32 & 1312 & Noutro1 \\
\hline$\gamma$ & to receive students' assignments & $\%$ & 22.6 & 25.8 & 21.8 & 18.5 & 11.3 & 3.3 & 1.313 & Neutral \\
\hline & I prefer to use social media to & Frequency & 21 & 39 & 33 & 18 & 13 & & & \\
\hline 9 & $\begin{array}{c}\text { provide students with } \\
\text { information regarding their } \\
\text { courses }\end{array}$ & $\%$ & 16.9 & 31.5 & 26.6 & 14.5 & 10.5 & 3.3 & 1.216 & Neutral \\
\hline & I think that using social media & Frequency & 51 & 51 & 14 & 5 & 3 & & & \\
\hline 10 & $\begin{array}{l}\text { enables me to contact people } \\
\text { with a common interest in the } \\
\text { field of specialization }\end{array}$ & $\%$ & 41.1 & 41.1 & 11.3 & 4 & 2.4 & 4.15 & 0.943 & Agree \\
\hline & I think that using social media & Frequency & 35 & 46 & 22 & 10 & 11 & & & \\
\hline 11 & $\begin{array}{l}\text { helps me to keep in touch with } \\
\text { students beyond the school } \\
\text { walls }\end{array}$ & $\%$ & 28.2 & 37.1 & 17.7 & 8.1 & 8.9 & 3.68 & 1.22 & Agree \\
\hline & I believe that there are some & Frequency & 34 & 46 & 28 & 11 & 5 & & & \\
\hline 12 & $\begin{array}{l}\text { topics which can be presented } \\
\text { through social media networks }\end{array}$ & $\%$ & 27.4 & 37.1 & 22.6 & 8.9 & 4 & 3.75 & 1.079 & Agree \\
\hline & I see that with social media I & Frequency & 24 & 48 & 27 & 18 & 7 & & & \\
\hline 13 & $\begin{array}{c}\text { can follow up the students' } \\
\text { learning progress }\end{array}$ & $\%$ & 19.4 & 38.7 & 21.8 & 14.5 & 5.6 & 3.52 & 1.13 & Agree \\
\hline 14 & I believe that social media is a & Frequency & 29 & 65 & 14 & 9 & 7 & 381 & 1057 & Agree \\
\hline & responsive teaching tool & $\%$ & 23.4 & 52.4 & 11.3 & 7.3 & 5.6 & & & Agree \\
\hline 15 & Social media is more efficient & Frequency & 32 & 58 & 18 & 14 & 2 & 384 & 0991 & A oree \\
\hline 15 & in obtaining feedback & $\%$ & 25.8 & 46.8 & 14.5 & 11.3 & 1.6 & 3.84 & 0.991 & Agree \\
\hline & I think that social media in the & Frequency & 50 & 42 & 24 & 2 & 6 & & & \\
\hline 16 & $\begin{array}{c}\text { future will play a significant } \\
\text { role in education }\end{array}$ & $\%$ & 40.3 & 33.9 & 19.4 & 1.6 & 4.8 & 4.03 & 1.051 & Agree \\
\hline 17 & I believe that social media & Frequency & 43 & 44 & 20 & 11 & 6 & 3.86 & 1.136 & Agree \\
\hline
\end{tabular}




\begin{tabular}{|c|c|c|c|c|c|c|c|c|c|c|}
\hline & $\begin{array}{l}\text { broadens the student's learning } \\
\text { horizon as it keeps him well } \\
\text { informed of the latest in the } \\
\text { field of study }\end{array}$ & $\%$ & 34.7 & 35.5 & 16.1 & 8.9 & 4.8 & & & \\
\hline \multirow[b]{2}{*}{18} & I think that social media & Frequency & 30 & 55 & 23 & 10 & 6 & \multirow[b]{2}{*}{3.75} & \multirow[b]{2}{*}{1.064} & \multirow[b]{2}{*}{ Agree } \\
\hline & $\begin{array}{l}\text { encourages students to be } \\
\text { positive and interactive }\end{array}$ & $\%$ & 24.2 & 44.4 & 18.5 & 8.1 & 4.8 & & & \\
\hline \multirow[b]{2}{*}{19} & \multirow{2}{*}{$\begin{array}{l}\text { Social media helps to change } \\
\text { the role of the teacher from a } \\
\text { prompter to a supervisor and a } \\
\text { follower in the teaching process }\end{array}$} & Frequency & 38 & 50 & 21 & 9 & 6 & \multirow[b]{2}{*}{3.85} & \multirow[b]{2}{*}{1.09} & \multirow[b]{2}{*}{ Agre } \\
\hline & & $\%$ & 30.6 & 40.3 & 16.9 & 7.3 & 4.8 & & & \\
\hline \multirow[b]{2}{*}{20} & Social media promotes & Frequency & 40 & 51 & 21 & 8 & 4 & \multirow[b]{2}{*}{3.93} & \multirow[b]{2}{*}{1.022} & \multirow[b]{2}{*}{ Agree } \\
\hline & $\begin{array}{l}\text { students' learning more } \\
\text { efficiently than traditional tools }\end{array}$ & $\%$ & 32.3 & 41.1 & 16.9 & 6.5 & 3.2 & & & \\
\hline Total & & & & & & & & 3.83 & 0.794 & Agree \\
\hline
\end{tabular}

As shown in Table 2, the participants strongly agreed on the first item "I believe that social media is easy to use" with (mean $=4.5, \operatorname{stdv}=0.618$ ) but were neutral on two items, namely, "I would rather use social media to receive students' assignments" (mean $=3.3, \mathrm{stdv}=1.313$ ) and "I prefer to use social media to provide students with information regarding their courses" (mean $=3.3, \mathrm{Stdv}=1.216)$. Also, they were in agreement with all other items. In total, the participants agreed with the use of social media in teaching (mean $=3.83$, stdv $=0.794)$. This result tends to suggest that the attitudes of the teachers of Islamic Education in the city of Ha'il towards the use of social media in the educational process are positive. This result is consistent with the findings of Al-Otaibi, (2018), Siha and Bell (2013) and Acarli and Sağlam (2015) who pointed to the positive trends towards the use of social media and its importance in the educational process. Based on this, it can be inferred that this result reflects the importance of social media and their role in the present era. As Salem (2017) pointed out, the importance and impact of social media have continued to grow globally over the past decade. Therefore, among the implications of this result is that those responsible for the educational process need to pay close attention to the training of teachers by helping them acquire the necessary skills to effectively employ social media in teaching and learning.

4.2 Question Two: What Are the Purposes for Which Social Media Used by Teachers of Islamic Education in Ha'il in the Educational Process?

The questionnaire included items related to the purposes of social media use by teachers. The items investigated the participants' purposes for using social media focusing on three aspects: personal, educational, and social purposes. Table 3 and Figure 1 below show the distribution of teachers according to these purposes.

Table 3. The objectives intended in using social media

\begin{tabular}{cccc}
\hline No. & objectives intended in using social media & Frequency & $\%$ \\
\hline 1 & Personal & 65 & 52.4 \\
2 & Educational & 11 & 8.9 \\
3 & Social & 48 & 38.7 \\
\hline
\end{tabular}




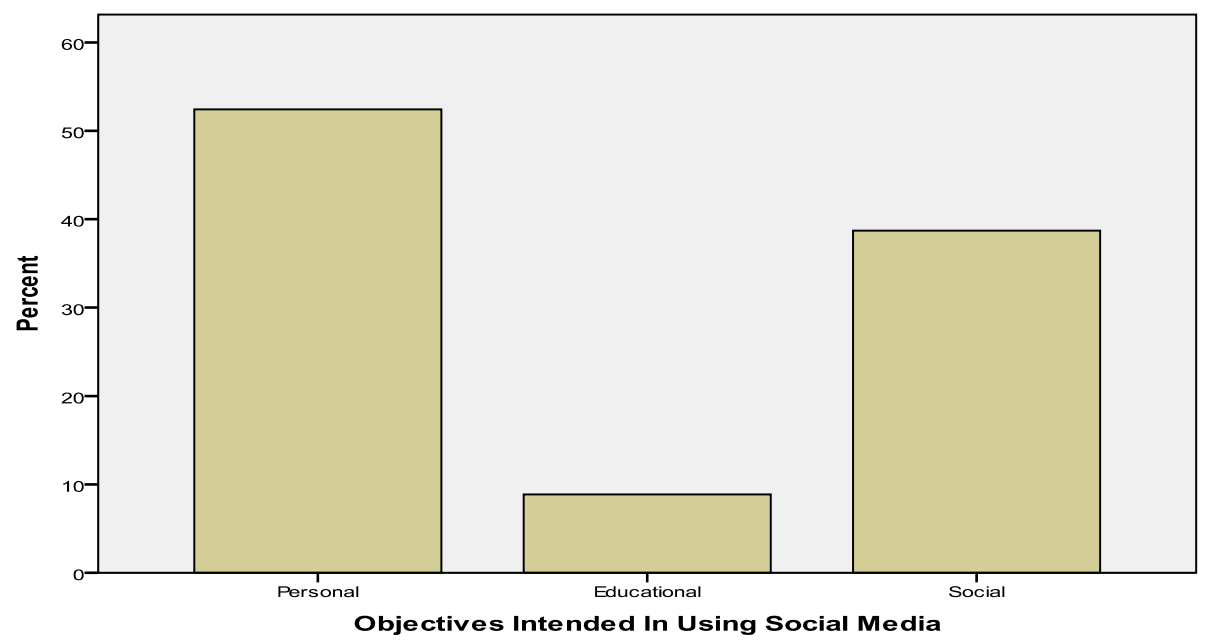

Figure 1. The objectives intended in using social media

Table 3, shows that $52.4 \%$ of the teachers involved in this study use social media for personal purposes while $38.7 \%$ of them used social media for social matters. A small proportion of Islamic education teachers $(8.9 \%)$, however, used social media for educational aspects. The results indicate that the use of social media for educational purposes was low, and that the highest proportion of use was for personal purposes. Hence, these results tend agree with the findings of Ibrahim (2014), Al-Sadhan (2015), Al-Ghamlas and Al-Qumaizi (2016) and Siha and Bell (2013) that there is a poor use of social media in teaching and learning. This percentage, as shown by Al-Sadhan (2015), is low in comparison to what is happening today in the world given the rapid technological developments in various fields, including education. The low rate of teachers' use of social media in education may be attributed to teachers' lack of knowledge as educational tools and due to their lack of skills in employing them in teaching and learning.

4.3 Question Three: What Are the Difficulties That the Teachers of Islamic Education in Ha'Il Are Facing When Using Social Media in the Educational Process?

The mean and standard deviation of the questionnaire items about the difficulties faced by teachers when using social media in teaching and learning were calculated. The questionnaire investigated the challenges faced by participants using a Likert scale. Table 4 shows the means and standard deviation in addition to the result according to the five-point Likert for the items relating to the challenges.

Table 4. Challenges faced by teachers to use social media in teaching

\begin{tabular}{|c|c|c|c|c|}
\hline No. & Statement & Mean & Stdv & Result \\
\hline 1 & Not all students have computers or smartphones & 1.98 & 1.14 & Disagree \\
\hline 2 & No manual about using social media in teaching is available for teachers & 1.79 & 0.94 & $\begin{array}{l}\text { Strongly } \\
\text { Disagree }\end{array}$ \\
\hline 3 & Not all students have computers or smartphones & 2.27 & 1.16 & Disagree \\
\hline 4 & Some people think that social media distracts students from topic and lesson & 2.55 & 1.14 & Disagree \\
\hline 5 & $\begin{array}{l}\text { The weak interaction between the student and the teacher when presenting the course content and } \\
\text { exercises on social media }\end{array}$ & 2.66 & 1.15 & Neutral \\
\hline 6 & The student lacks the skills needed to use social media & 2.41 & 1.1 & Disagree \\
\hline 7 & $\begin{array}{l}\text { The teacher's inability to distinguish between academic and personal topics when using social } \\
\text { media }\end{array}$ & 2.61 & 1.12 & Neutral \\
\hline 8 & The teacher's unwillingness to use social media & 2.51 & 1.02 & Disagree \\
\hline 9 & Using social media requires extra effort from the teacher outside school & 2.16 & 1.11 & Disagree \\
\hline 10 & The teacher's worry about the confidentiality of the information & 2.44 & 1.09 & Disagree \\
\hline 11 & The teacher's inability to control the discussions & 2.51 & 1.13 & Disagree \\
\hline 12 & Using nick names makes it difficult to recognize students' real identities & 2.05 & 1.09 & Disagree \\
\hline Total & & 2.33 & 0.69 & Disagree \\
\hline
\end{tabular}


As shown in Table 4 above, the participants strongly disagreed with the second item "no manual about using social media in teaching is available for teachers" (mean $=1.79$, stdv $=0.94)$ but they were neutral on two items, namely "the weak interaction between the student and the teacher when presenting the course content and exercises on social media" ( mean $=2.66, \mathrm{stdv}=1.15)$ and "the teacher's inability to distinguish between academic and personal topics when using social media" ( mean $=2.61, \mathrm{stdv}=1.12$ ). However, participants were in disagreement with all other items. In total, the participating Islamic Education teachers disagreed with having challenges in using social media in teaching $($ mean $=2.33$, stdv $=0.69)$.

The above results show that teachers did not see any obstacles to their use of social media in teaching and learning. Hence, this result contradicts the studies of Al-Sadhan (2015) and Al-Otaibi (2018) which identified several obstacles to the use of social media in education. For example, they found that the most important challenge was the lack of training courses available for teachers to help them use social media in education and the need for time and effort, the absence of incentives for teachers and the poor infrastructure. This result, which contradicts most other Saudi studies, may be attributed to the participants' low use of social media for educational purposes, as indicated by the results related to the second research question. This leads to the conclusion that teachers who do not use social media for educational purposes may not even notice any obstacles to use social media for educational purposes.

\section{Conclusion}

This study sought to identify the attitudes of Islamic Education teachers in Ha'il towards the use of social media in the educational process. The study particularly examined teachers' purposes and challenges of using social media in relation to teaching and learning. The findings showed that Islamic Education teachers had positive attitudes towards the use of social media and its importance in the educational process. The participants' proclivity of social media for personal reasons explains that integrating social media for educational purposes presupposes teachers' knowledge and skills about the methods of using them. In order to prepare teachers for the use of social media, policy makers, teacher educators and managers should develop and offer training courses that address the teachers' needs. Finally, it also seems important to conduct further studies investigating the best ways to employ social media in the process of teaching and learning so as to take advantages of these tools.

\section{References}

Abdulhafez, H. (2012, September 2). Education Through Social Networks Advantages and Disadvantages. Retrieved from http://www.almarefh.net/show_content_sub.php?CUV=399\&SubModel=138\&ID=1646

Acarli, D. S., \& Sağlam, Y. (2015). Investigation of pre-service teachers' intentions to use of Social Media in Teaching Activities within the Framework of Technology Acceptance Model. Procedia-Social and Behavioral Sciences, 176, 709-713. https://doi.org/10.1016/j.sbspro.2015.01.530

Aifan, H. (2010). The Effect of Facebook on Saudis' Interpersonal Relationships with the others (Unpublished doctoral thesis). University of Kansas.

Al-Anzi, J. Z. (2013). Effectiveness of the use of social media in the collection of science and the trend towards the knowledge society among students of the third grade in Medina (Unpublished doctoral thesis). Umm Al Qura University, Makkah Al Mukarramah, Saudi Arabia.

Al-Ghamlas, K., \& Al-Qumaizi, H. (2016). The extent of employing social media in the teaching and learning processes in Saudi universities from the point of view of faculty members. The Arab Journal of Educational and Social Studies, 8, 45-88.

Al-Maliki, M., \& Al-Mas'ad, A. (2017). The role of social media in the development of teaching practices for male and female teachers of mathematics in the middle and secondary stages from their point of view. Arabic Studies in Education and Psychology, 82, 65-91.

Al-Otaibi, G. (2018). The reality of the employment of social media (Facebook and Twitter) in education from the point of view of secondary and middle school teachers in the city of Riyadh. Journal of Faculty of Education of Assiut, 3(34), 219-249.

Al-Sadhan, A. (2015). The reality of the use of social networks in teaching university faculty members at King Saud University. Journal of the Faculty of Education of Ain Shams, 4(39), 537-588.

Al-Yahya, N. (2014), Using Social Networking Sites in Higher Education: A Field Study at Princess Noura Bint Abdulrahman University. Journal of Information Studies, 11, 93-122.

Cohen, L., Manion, L., \& Morrison, K. (2000). Research methods in education. London: Routledge Falmer. 
Dabbagh, N., \& Reo, R. (2011). Impact of Web 2.0 on higher education. In D. W. Surry, T. Stefurak, \& R. Gray (Eds.), Technology integration in higher education: Social and organizational aspects (pp. 174-187). https://doi.org/10.4018/978-1-60960-147-8.ch013

Hassanein, B. (2013). Employment of social media in science education and learning. Research presented to the Seventh Arab Scientific Conference (Education and Culture of Social Communication), Sohag 24-25 April 2012. Egypt.

Hurn, K. (2012). The impact of social software in product design higher education. Design and Technology Education: An International Journal, 17(2), 35-48.

Ibrahim, K. (2014). The extent of the use of faculty members and students for social networks in the educational process in universities in Upper Egypt (field study). Journal of Educational Sciences, 3(2), 414-476.

Kale, U., \& Goh, D. (2012). Teaching style, ICT experience and teachers' attitudes toward teaching with Web 2.0. Education and Information Technologies, 19(1), 41-60. https://doi.org/10.1007/s10639-012-9210-3

Redecker, C., Ala-Mutka, K., \& Punie, Y. (2010). Learning 2.0-The Impact of Social Media on Learning in Europe. Luxembourg: Office for Official Publications of the European Communities.

Roebuck, D., Siha, S., \& Bell, R. L. (2013). Faculty usage of social media and mobile devices: Analysis of advantages and concerns. Interdisciplinary Journal of E-Learning and Learning Objects, 9, 171-192. https://doi.org/10.28945/1914

Salem, F. (2017). The Arab Social Media Report 2017: Social Media and the Internet of Things: Towards Data-Driven Policymaking in the Arab World (Vol. 7). Dubai: MBR School of Government.

Soomro, K. A., Kale, U., \& Zai, S. Y. (2014). Pre-service teachers' and teacher educators' experiences and attitudes toward using social networking sites for collaborative learning. Educational Media International, 51(4), 278-294. https://doi.org/10.1080/09523987.2014.977003

Taha, N. (2016). The reality of employing social media in supporting the educational process and activating it among students of educational diploma, Faculty of Education, Taif University. Arabic Studies in Education and Psychology, Special issue, 141-161.

Yuen, S. C., Yaoyuneyong, G., \& Yuen, P. K. (2011). Perceptions, interest, and use: Teachers and web 2.0 tools in education. International Journal of Technology in Teaching \& Learning, 7(2), 109-123.

\section{Copyrights}

Copyright for this article is retained by the author(s), with first publication rights granted to the journal.

This is an open-access article distributed under the terms and conditions of the Creative Commons Attribution license (http://creativecommons.org/licenses/by/4.0/). 